\title{
In situ measurements of hydraulic properties of a shear zone in northwestern South Carolina
}

\author{
Pradeep Talwani and Jason S. Cobb \\ Department of Geological Sciences, University of South Carolina, Columbia \\ Malcolm F. Schaeffer \\ Duke Engineering and Services, Inc., Charlotte, North Carolina
}

\begin{abstract}
Subsequent to the initial impoundment of the Bad Creek Reservoir in northwest South Carolina in January 1991, lake level fluctuations (up to $33 \mathrm{~m} \mathrm{~d}^{-1}$ ) caused delayed (98 hours) correlative water level changes in an observation well (OW3) $250 \mathrm{~m}$ away. The bottom of the well is connected to the bottom of the reservoir by a shallowly dipping, $1 \mathrm{~m}$ wide shear zone. The amplitude of water level changes in OW3 was 0.19 of that in the reservoir. The amplitude ratio, $R$, of the water level changes in OW3 to those in the reservoir is a measure of the pore pressure transmitted through the shear zone. Assuming one-dimensional diffusion of pore pressure in the shear zone between the reservoir and OW3, these values of time lag and amplitude ratio of the water level fluctuations changes yield estimates of $0.05 \mathrm{~m}^{2} \mathrm{~s}^{-1}$ for hydraulic diffusivity and $1.1 \times$ $10^{-15} \mathrm{~m}^{2}$ for permeability of the shear zone. In subsequent years the time lag decreased to 72 hours and $R$ increased to 0.23 , suggesting a nearly $60 \%$ increase in the two hydraulic parameters. We interpret the increase to be owing to flushing of fines in the shear zone due to the pumping action of lake level fluctuations or due to dissolution. After 1994, there were no further changes in these parameters suggesting steady state conditions. Our analysis demonstrated that the fluid pressure flow is restricted to the shear zone and the pore pressure transmitted through the shear zone showed a lognormal relationship with the frequency of lake level fluctuations, $R=0.5 \exp (-14.93 / T)$, where $T$ (days) is the period of lake level changes. Spectral analyses of the data were used to obtain a frequency independent hydraulic diffusivity $\left(\sim 0.076 \mathrm{~m}^{2} \mathrm{~s}^{-1}\right)$ of the shear zone after it had reached steady state conditions. Using the undrained response of the reservoir, an in situ estimate value 0.66 was obtained for the Skempton's coefficient. The hydraulic diffusivity $\sim 0.1 \mathrm{~m}^{2}$ $\mathrm{s}^{-1}$ was found to be lower than that encountered at other locations of induced seismicity in the region.
\end{abstract}

\section{Introduction}

Both theoretical models and observations attest to the importance of pore pressure diffusion in triggering tectonic and induced seismicity [see, e.g., Healy et al., 1968; Nur and Booker, 1972; Howells, 1974; Talwani, 1976; Hill, 1977; Bell and Nur, 1978; Hsieh and Bredehoeft, 1981; Talwani and Acree, 1984; Roeloffs, 1988; Rice, 1992; Rajendran and Talwani, 1992; Henderson and Maillot, 1997; Talwani, 1997]. However, in all cases, the value of the critical hydraulic parameter, hydraulic diffusivity, was assumed or inferred, for example, from the spreading of seismicity [e.g., Talwani and Acree, 1984; Shapiro et al., 1997] or the lag between the onset of seismicity and impoundment of reservoirs [Talwani and Acree, 1984]. This study is perhaps the first, direct in situ measurement of hydraulic diffusivity in a shear zone. The hydraulic diffusivity and therefrom the in situ permeability of a $1 \mathrm{~m}$ wide shear zone, were obtained by comparing the lake levels in the Bad Creek Reservoir with those in an observation well connected to the reservoir by the shear zone. Here we present the results of monitoring of the water levels, the estimation of in situ hydraulic diffusivity

Copyright 1999 by the American Geophysical Union.

Paper number 1999JB900059.

0148-0227/99/1999JB900059\$09.00 and permeability of the shear zone, and the temporal behavior of these parameters. On a spatial scale of approximately hundreds of meters and a temporal scale of several days, the hydraulic parameters of the shear zone were found to be homogeneous. These data also show a frequency dependence of pore pressures transmitted through a saturated shear zone. The high-frequency observations were used to obtain an in situ estimate of the Skempton's coefficient.

\subsection{Bad Creek Project}

The Bad Creek Project, located in the Blue Ridge geologic province in northwestern South Carolina, is a $1000 \mathrm{mw}$ hydroelectric pumped storage facility consisting of four reversible pump turbines in a powerhouse $200 \mathrm{~m}$ underground. The above ground structures consist of two large dams and a saddledike, which forms the upper Bad Creek Reservoir and the intake and discharge structures [Schaeffer, 1987]. The Bad Creek Project consists of an upper reservoir, a lower reservoir, and a $9.1 \mathrm{~m}$ diameter power tunnel connecting both pools. Lake Jocassee serves as the lower reservoir and as the main supply of water for Bad Creek Reservoir (Figure 1).

Bad Creek Reservoir was impounded between January 4 and March 8, 1991, behind a $110 \mathrm{~m}$ high main dam, a $52 \mathrm{~m}$ high west dam, and a $27 \mathrm{~m}$ high east dike with a full pond surface 


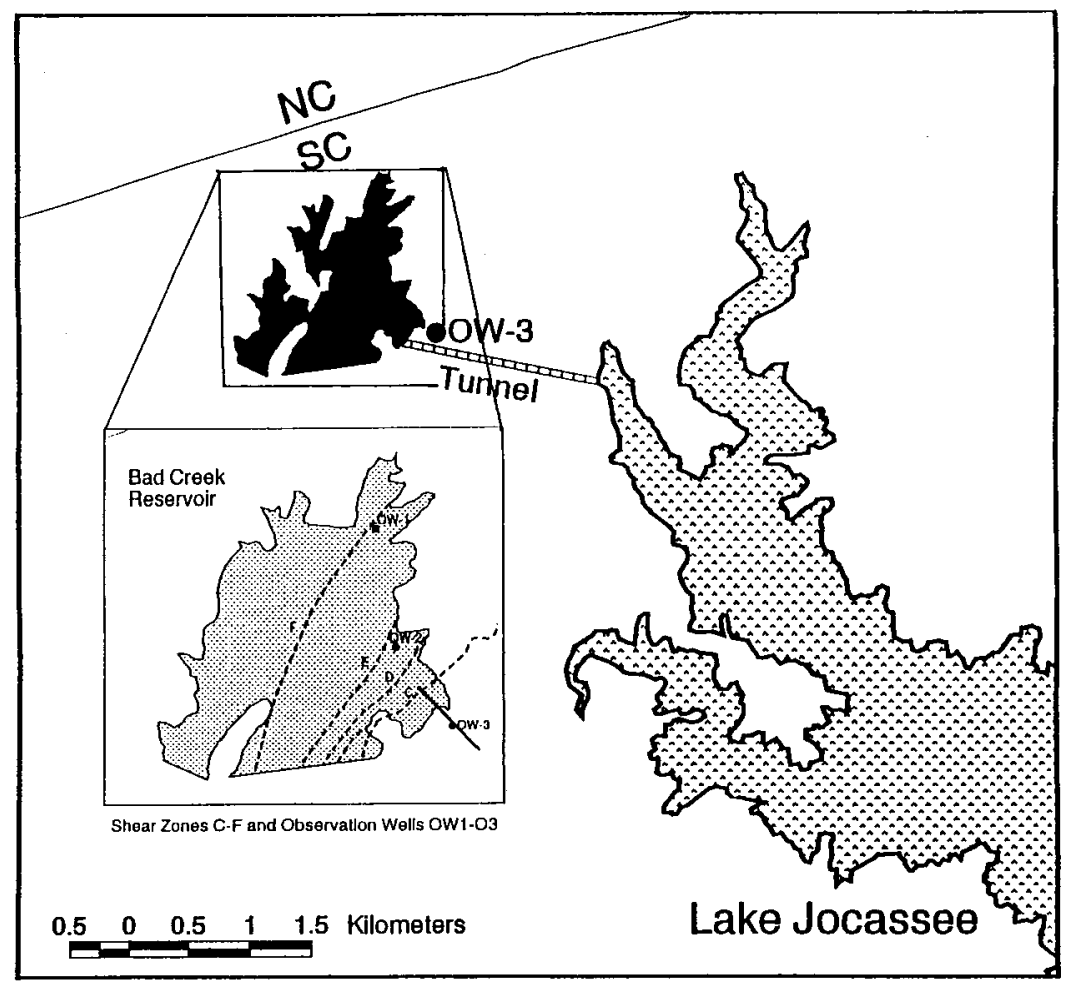

Figure 1. Map showing the location of Bad Creek Reservoir in northwestern South Carolina. Inset shows the location of shear zones and observation wells.

area and volume of $1.26 \times 10^{6} \mathrm{~m}^{2}$ and $33.5 \times 10^{6} \mathrm{~m}^{3}$, respectively; a small reservoir compared to other locations of reservoir induced seismicity (RIS). However, because of a maximum drawdown of $48.8 \mathrm{~m}$ at rates as high as $3.8 \mathrm{~m} \mathrm{~h}^{-1}$, Bad Creek Reservoir was chosen for a study of the effect of rate of impoundment on RIS [Talwani et al., 1990].

To generate electricity during times of peak energy demand, water flows from Bad Creek Reservoir (full pond elevation $704 \mathrm{~m}$ (2309 feet)) through an intake structure at an elevation of $636 \mathrm{~m}$ and then through the power tunnel to an underground powerhouse near Lake Jocassee at an elevation of 315 m. During off-peak hours, Duke Power Company reverses the pump turbines to pump the water back into Bad Creek Reservoir from Lake Jocassee. The Bad Creek Reservoir can be emptied in 1 day and refilled in 4 days.

\subsection{Shear Zones}

The Bad Creek Project is located within the Toxaway Dome in the Blue Ridge geologic province, immediately northwest of the Brevard zone in South Carolina [Hatcher, 1977]. The dome is flanked on all sides by rocks of the Tallulah Falls Formation. It is an elongate feature that has a steeply dipping to overturned northwest limb and a more moderately inclined southwest limb. At the ends, the structure plunges gently northeast and southwest, resulting in a structural dome defined by upward arching of the dominant foliation.

At least two episodes of flowage folding have been recognized in the Toxaway Dome. The first set is isoclinal and recumbent, trending east to northeast and verging north to northwest. The second set is more upright, isoclinal to open, trending northeast and verging northwest.

Shear zones with thicknesses of up to $1 \mathrm{~m}$ occur throughout the Toxaway gneiss and are related to the second episode of folding. Superposed on the ductile shearing is a later brittle deformation which also formed high-angle fault zones.

In conjunction with the construction of dams and intake tunnels, six shear zones, dipping southeast and roughly parallel to each other, were discovered [Schaeffer et al., 1989; Talwani, 1990]. Numerous drilling logs and detailed surface mapping revealed that the shear zones dip to the southeast at angles from $20^{\circ}$ to $40^{\circ}$ [Schaeffer et al., 1989; Widdowson et al., 1991]. Four of these shear zones outcropped within the Bad Creek Reservoir (Figures 1 and 6a). Shear zone $\mathrm{C}$ lies under the east dike and was the subject of detailed geotechnical investigations. These shear zones are hydraulically connected to the reservoir, facilitating the transmission of pore pressure to greater depths.

Shear zone $C$ in the reservoir consists of sheared areas $0.6-1$ $\mathrm{m}$ thick (Plate 1) with alternating layers of hard material (discontinuous quartz-feldspar pegmatites and breccia with an epidote-chlorite matrix) and softer material (weathered sheared rock, weathered granitic gneiss, and discontinuous lenses of biotite schist). A 1-25 cm thick discontinuous phyllonite layer occurs along the major sheared areas. Several well-defined planes within the sheared area contain discontinuous clay layers up to $5 \mathrm{~cm}$ thick. The discontinuous hard breccia layers are generally highly fractured with intense iron and manganese staining occurring throughout, indicating water circulation in the shear zone. Some portions of the shear zone have up to 18 $\mathrm{cm}$ of gouge-breccia comprised of rock, quartz-feldspar fragments, and vein quartz in a clay matrix. Secondary minerals in the shear zone include quartz and calcite. The shear planes are not uniformly permeable, and the zones of high permeability are probably related to the relatively thin, hard layers of fractured pegmatite and breccia in the zone [Schaeffer et al., 1989]. 


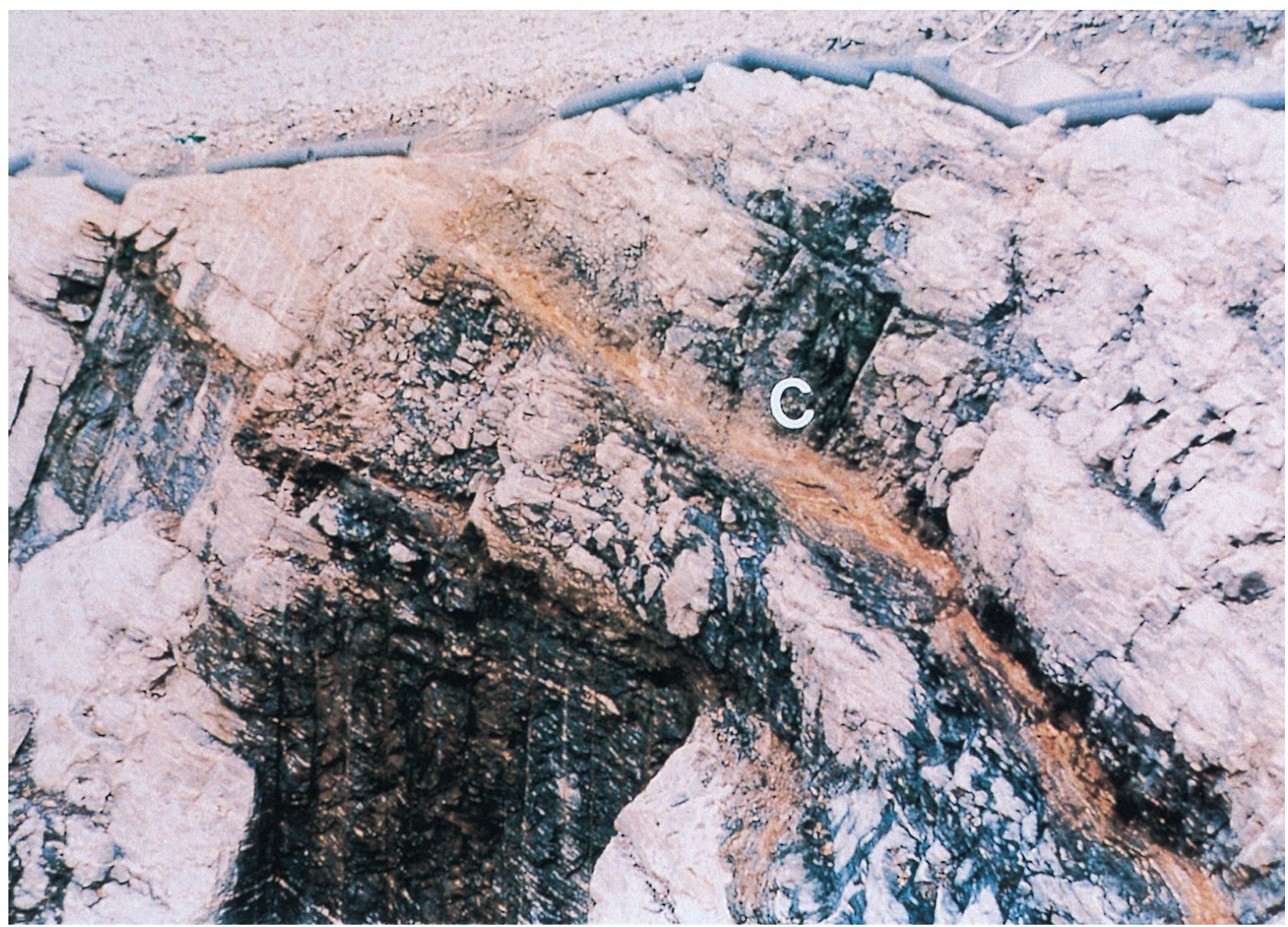

Plate 1. View of northeast and southeast walls of the intake structure showing the $1 \mathrm{~m}$ thick yellow-brown southeast dipping shear zone $\mathrm{C}$.

\subsection{Instrumentation}

The locations and dips of the shear zones mapped at the surface and in the tunnels were used to choose sites for three observation wells, OW1, OW2, and OW3. OW1 and OW2 were spudded within the reservoir, whereas OW3 was located $\sim 250 \mathrm{~m}$ outside the reservoir (Figure 1). Each well was continuously cored to total depth (Table 1$)$ and a $3.05 \mathrm{~m}$ (10 feet) PVC slotted pipe with a slot size of $0.025 \mathrm{~cm}(0.010$ inches $)$ was installed at the depth where the borehole intersected the shear zone.

In OW3, the shear zone is $\sim 1 \mathrm{~m}$ thick and consists of sheared and fractured areas separated by relatively undeformed granitic gneiss. About $0.6 \mathrm{~m}$ of core was lost during drilling which probably corresponds to the softer, weathered portions of the shear zone observed elsewhere.
A pressure transducer was installed in the slotted pipe which was packed in a bed of pea gravel. The pressure transducers were open to the shear zones through $3.18 \mathrm{~cm}$ (1.25 inches) slotted screens. A bentonite seal separated the gravel from the formation above (Figure 2). A threaded cap was installed at the bottom of the PVC pipe.

The automated data acquisition system consisted of a fully submersible pressure transducer, a data-logger manufactured by Electronics Engineering Innovations, Inc., with a range 0-0.206 $\mathrm{MPa}$, and a power source. Data were retrieved using a laptop computer.

Monitoring of water levels in the observation wells began with the start of impoundment of Bad Creek Reservoir on January 4, 1991. Once OW1 and OW2 were submerged, the water levels in the wells were the same as in the reservoir

Table 1. Instrumentation History

\begin{tabular}{llll}
\hline & \multicolumn{1}{c}{ OW1 } & \multicolumn{1}{c}{ OW2 } & \multicolumn{1}{c}{ OW3 } \\
\hline Total depth & $24.63 \mathrm{~m}$ & $33.35 \mathrm{~m}$ & $126.13 \mathrm{~m}$ \\
Depth of slotted screen & $15.03-18.07 \mathrm{~m}$ & $27.25-30.30 \mathrm{~m}$ & $90.22-93.27 \mathrm{~m}$ \\
Intersects shear zone & $\mathrm{F}$ & $\mathrm{E}$ & $\mathrm{C}$ \\
Pressure transducer make & In Situ, Inc. & In Situ, Inc. & Omega Eng. \\
Range & $0-0.303 \mathrm{MPa}$ & $0-0.303 \mathrm{MPa}$ & $0-0.103 \mathrm{MPa}$ \\
Installation date & Oct. 3, 1990 & Sept. 28, 1990 & Nov. 12, 1990 \\
Initial recording ended on & June 14, 1991 & May 23, 1991 & Oct. 23, 1991 \\
\hline
\end{tabular}




\section{FRACTURED-ROCK PIEZOMETER DETAIL}

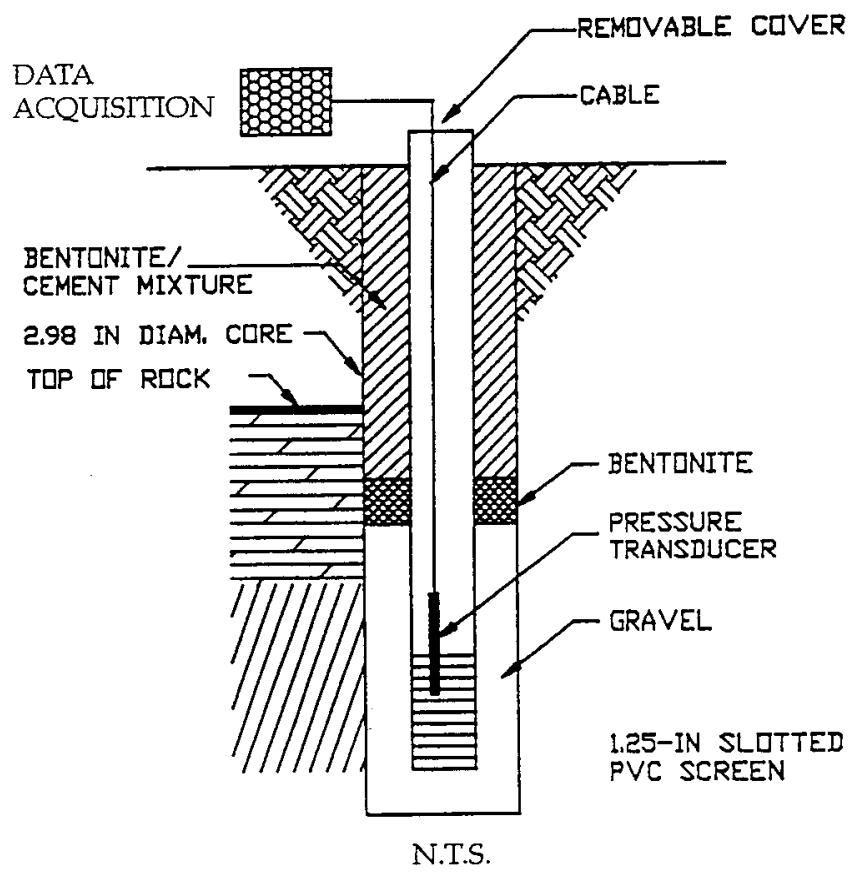

Figure 2. Schematic figure to show the data acquisition system at OW3. The pressure transducer is isolated from the top by a bentonite seal and is open to the shear zone through the slotted screen.

(Figure 3). The transducers in them failed on June 14 and May 23, 1991 (Table 1), and were not replaced.

OW3 showed a delayed and muted response. We continued to monitor OW3, but continuous data could not be obtained because of breakdowns, lightning strikes, and time lost in repairing and replacing the transducers. Data were obtained intermittently from March 12 to December 29, 1992, August 11, 1994 to January 19, 1995, July 19 to September 10, 1995, and from November 13, 1995, to the end of 1996. In 1991 and 1992, water levels in the observation wells were recorded every $15 \mathrm{~min}$, and after 1994, they were recorded every $30 \mathrm{~min}$.

\section{Observations}

After the initial impoundment (Figure 3), the water level fluctuations in OW3 closely resembled those in the reservoir but with a discernible delay. Cross correlation between the time series representing the water levels for the period June 15 to December 1, 1992, showed that the maximum correlation coefficient (0.80) corresponded to a 98 hour lag [Cobb, 1997]. Figure 4a compares the water level of the reservoir (shifted by 98 hours) with that in OW3 (plotted on an enlarged scale). We note that there is excellent agreement between the two curves, both in their long period and short period behavior. The observation that there is a near perfect match in the short period (24 hours) fluctuations (Figure 5) suggests that the shear zone is saturated.

We interpret these observations as follows: Lake level changes about a mean level, $\Delta L$, result in corresponding pore fluid pressure changes at the bottom of the lake on top of the shear zone. These pore pressures are transmitted through the shear zone arriving at the bottom of OW3 98 hours later. The water level changes in OW3 about a mean level, $\Delta W$, are a measure of the pore pressure changes at the bottom of OW3 in the shear zone. On the basis of the assumption of onedimensional (1-D) fluid pressure diffusion,

$$
\partial^{2} p / \partial r^{2}=(1 / C) \partial p / \partial t
$$

where $p$ is the fluid pressure and $C$ is the hydraulic diffusivity $\left(\mathrm{m}^{2} \mathrm{~s}^{-1}\right)$. Neglecting poroelastic compression, the ratio of the

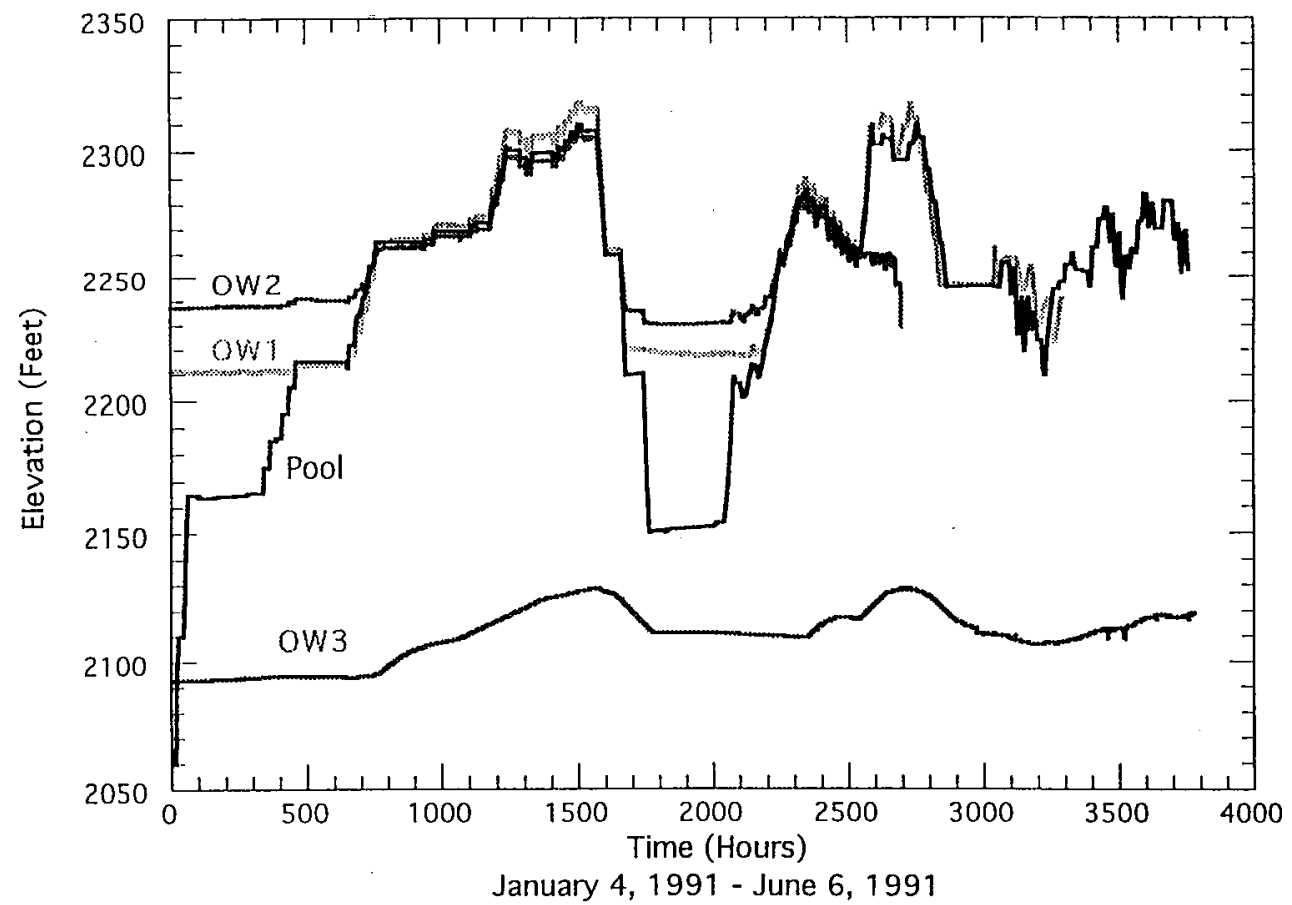

Figure 3. Initial filling curve for the Bad Creek Reservoir (pool) and the observation wells from January 4 to June $6,1991$. 

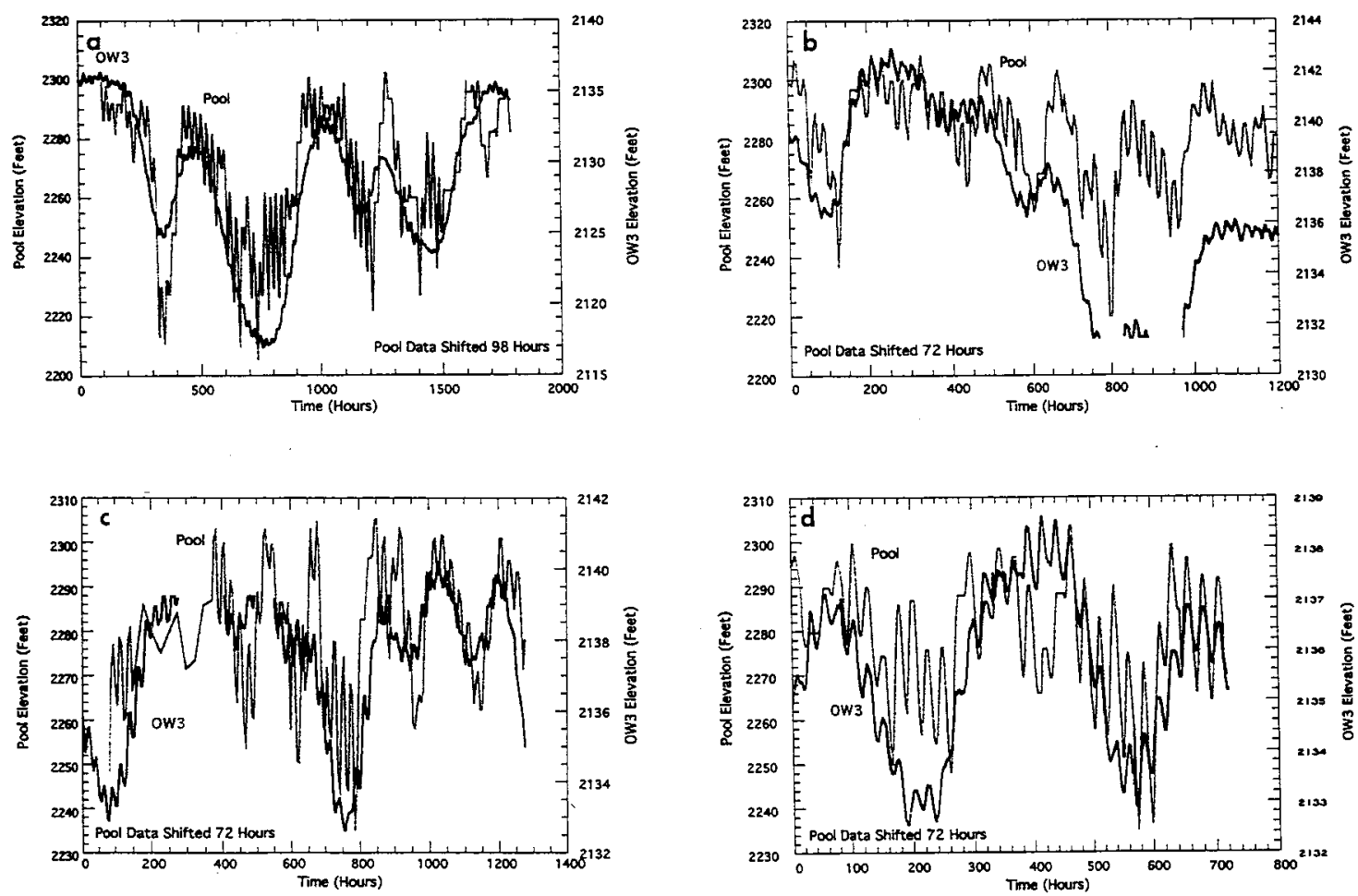

Figure 4. Comparison of water levels in the lake and OW3. The lake levels have been shifted by the time lag. (a) June 15 to August 29, 1992, (b) August 11 to September 11, 1994, (c) July 19 to September 10, 1995; and (d) June 1 to July 1, 1996. Note how well the water level changes in OW3 mimic those in the reservoir at both long and short periods.

water level changes, $R=\Delta W / \Delta L$, is a measure of the pressure changes, i.e.,

$$
R=\Delta W / \Delta L=p(r, t+\Delta t) / p(0, t)=1-\operatorname{erf}(r / 2 \sqrt{C \Delta t})
$$

where $p(0, t)$ and $p(r, t+\Delta t)$ are pore pressures in the shear zone at the bottom of the lake, at a time $t$ and at OW3, located

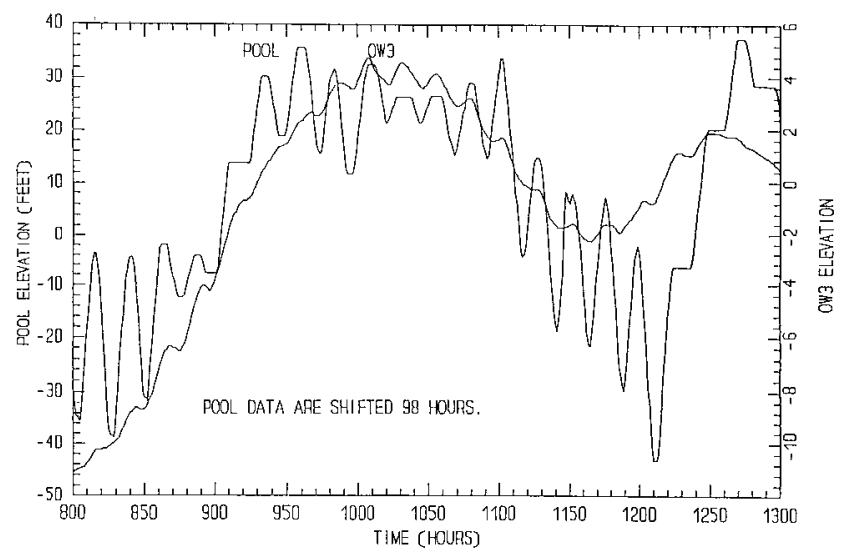

0W3 and Pool elev. from July 17 at 22:00 hs. to August 6 at 18:00 hs.

Figure 5. Comparison of water level changes with respect to the mean values for the lake and OW3 plotted on an enlarged scale. Note how well the short period ( 24 hours) changes in the lake are mimicked by OW3, suggesting that the shear zone is saturated. at a distance $r$ along the shear zone at a time $(t+\Delta t)$. Knowing $r, R$, and $\Delta t, C$ can be calculated from (2).

For the water level series in 1994 and after, $\Delta t$ was found to be 72 hours, with correlation coefficients of $0.80-0.72$ [Cobb, 1997]; that is, there was a reduction in the time lag between 1992 and 1994, after which the same time lag was observed through 1996. This observation suggested that the hydrologic system had reached steady state conditions. This observation is illustrated by comparing the water level in the reservoir, shifted 72 hours, with that in OW3 for the time periods August 11 to September 11, 1994, July 19 to September 10, 1995; and June 1 to July 1, 1996 (Figures 4b-4d). In each case, we find that the water level in OW3 mimics that in the reservoir with a delay of 72 hours.

\subsection{Ratios of Water Levels}

The ratio $R$ was obtained in two ways. First, $R$ was taken to be the ratio of the hourly differences from the mean water level in OW3 for a given period to the average of the hourly differences from the mean water in the lake but shifted by $\Delta t$. For the period June 15 to August 29, 1992, the average lake level was $690.34 \mathrm{~m}$ (2264.91 feet) and the average water level in OW3 was $648.74 \mathrm{~m}$ (2128.42 feet) (Figure 6b) [Talwani and $C o b b, 1997]$. The ratio of the average of the hourly departures of $\Delta W$ and $\Delta L$ was 0.19 .

The ratio $R$ was also calculated by taking the ratio of the corresponding largest changes in the water levels. For both the lake level and the water level in OW3, the deviations with respect to the mean were compared. For the period July 2 to August 6, 1992, the amplitudes of the largest departures from the mean water level are $3.63 \mathrm{~m}$ (11.9 feet) for OW3 and 19.45 


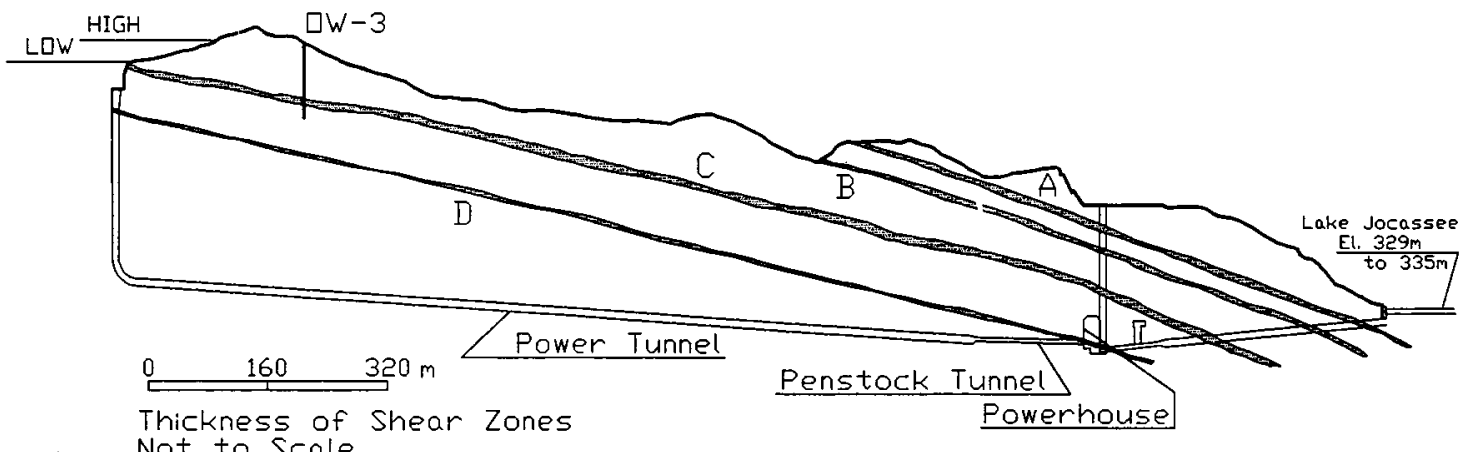

Q) Not to scale

$\mathrm{NW}$

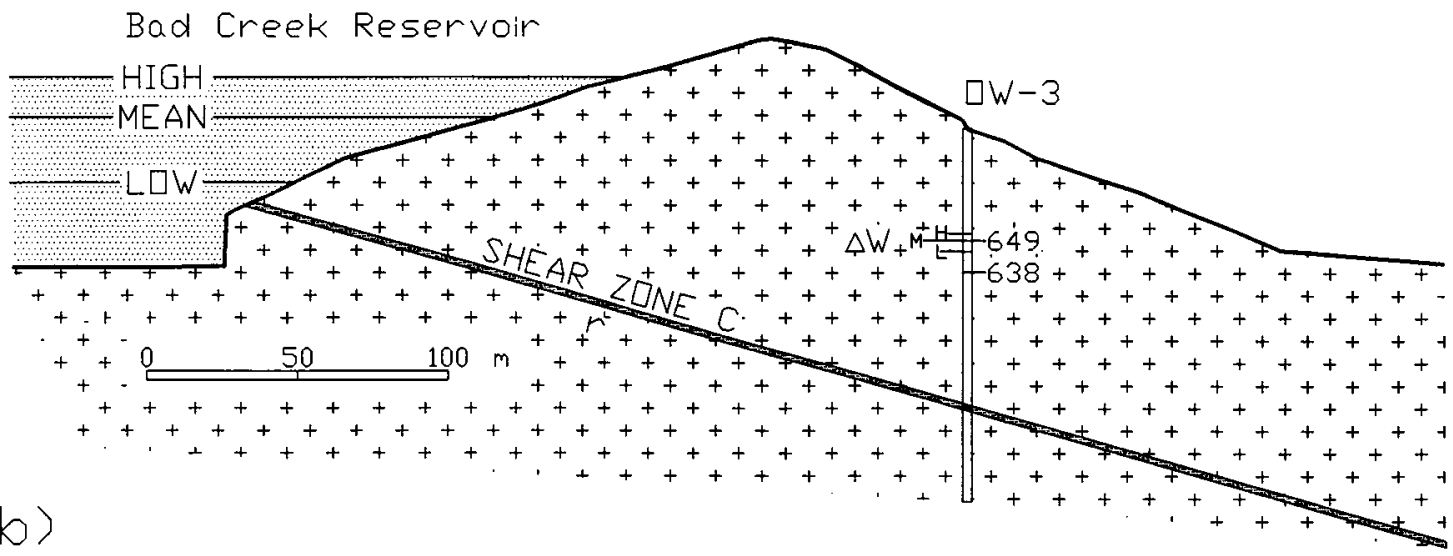

Figure 6. (a) Cross section of the Bad Creek Reservoir area showing locations of shear zones with respect to the intake structure located just below the low-water level and penstock and powerhouse areas. (b) A NW-SE cross section showing geometry of the Bad Creek Reservoir, shear zone C, and OW3. At the start of initial impoundment in 1991, the water level in OW3 was 638 m (2093 feet). Between June 15 and August 29, 1992, the water levels in the lake and OW3 fluctuated about mean values of $690 \mathrm{~m}$ and $649 \mathrm{~m}$, respectively. The slant line through OW3 in Figure 1 shows the location of the cross section shown here.

$\mathrm{m}$ (63.8 feet) for the lake, yielding a value of 0.19 for the amplitude ratio, $R$ (Figure 7a).

Amplitude ratios were calculated for other time periods and three examples are shown in Figures $7 b-7 d$, corresponding to August 11 to September 30, 1994, July 19 to September 10, 1995, and November 13, 1995 to April 12, 1996, respectively. (For other examples see Cobb [1997].) While the time lag, $\Delta t$, decreased, the amplitude ratios increased after 1992. These ratios and the corresponding delays, $\Delta t$, were used to calculate the hydraulic diffusivity, $C$, using (2). The results are given in Table 2.

\subsection{Estimating the Permeability}

Bodvarsson [1970] and Talwani and Acree [1984] related the hydraulic diffusivity, $C$, to the permeability of a medium, $k$, by the relation

$$
C=\frac{k}{\mu\left[\phi \beta_{f}+(1-\phi) \beta_{r}\right]}
$$

where $\mu, \phi, \beta_{f}$, and $\beta_{r}$ are fluid dynamic viscosity, rock porosity, and the compressibilities of fluid and rock, respectively.

A priori, we do not know if there is a temporal change in the porosity of the shear zone. If the porosity increases with time or remains constant, (3) suggests that an increase in the hydraulic diffusivity, $C$, implies an increase in the permeability. If we assume that $\mu, \phi, \beta_{r}$, and $\beta_{f}$ are unchanged, and using the following reasonable values, the permeability $k$ can be calculated. Assuming $\mu=$ viscosity of water $=10^{-2}$ poise $=10^{-3} \mathrm{~Pa}(\mathrm{~s}), \phi=$ porosity of fractured rock $=3 \times 10^{-3}$ [see, e.g., Brace, 1965], $\beta_{f}=$ effective compressibility of water $=4.6 \times 10^{-10} \mathrm{~Pa}^{-1}$, and $\beta_{r}=$ compressibility of rock $=2 \times 10^{-11} \mathrm{~Pa}^{-1}$, the observed hydraulic diffusivity of $0.0515 \mathrm{~m}^{2} \mathrm{~s}^{-1}$ corresponds to a permeability of $1.10 \times 10^{-15} \mathrm{~m}^{2}$ (1.10 millidarcy).

From Table 2 we note that after initial filling, the hydraulic diffusivity and permeability values were $\left(0.0515 \mathrm{~m}^{2} \mathrm{~s}^{-1}\right.$ and $1.10 \times 10^{-15} \mathrm{~m}^{2}$ ). In subsequent years, there was $\sim 60 \%$ increase in $C$ and $k$. We will discuss the significance of these values in section 5.4 .

\subsection{Permeability Measurements}

During the construction stage of the Bad Creek Project, the various shear zones were discovered and mapped [Schaeffer, 1987; Schaeffer et al., 1989]. Shear zone C was located where the east dike was to be constructed. Included among the various investigations was the sinking of several boreholes, many of which intersected the shear zone C. The "coefficient of permeability," $K$, was obtained by carrying out pumping-in tests [U.S. Bureau of Reclamation, 1974]. The shear zone was isolated by packers above and below the zone in the borehole. The pumping-in test therefore measured $K$ of the shear zone. 

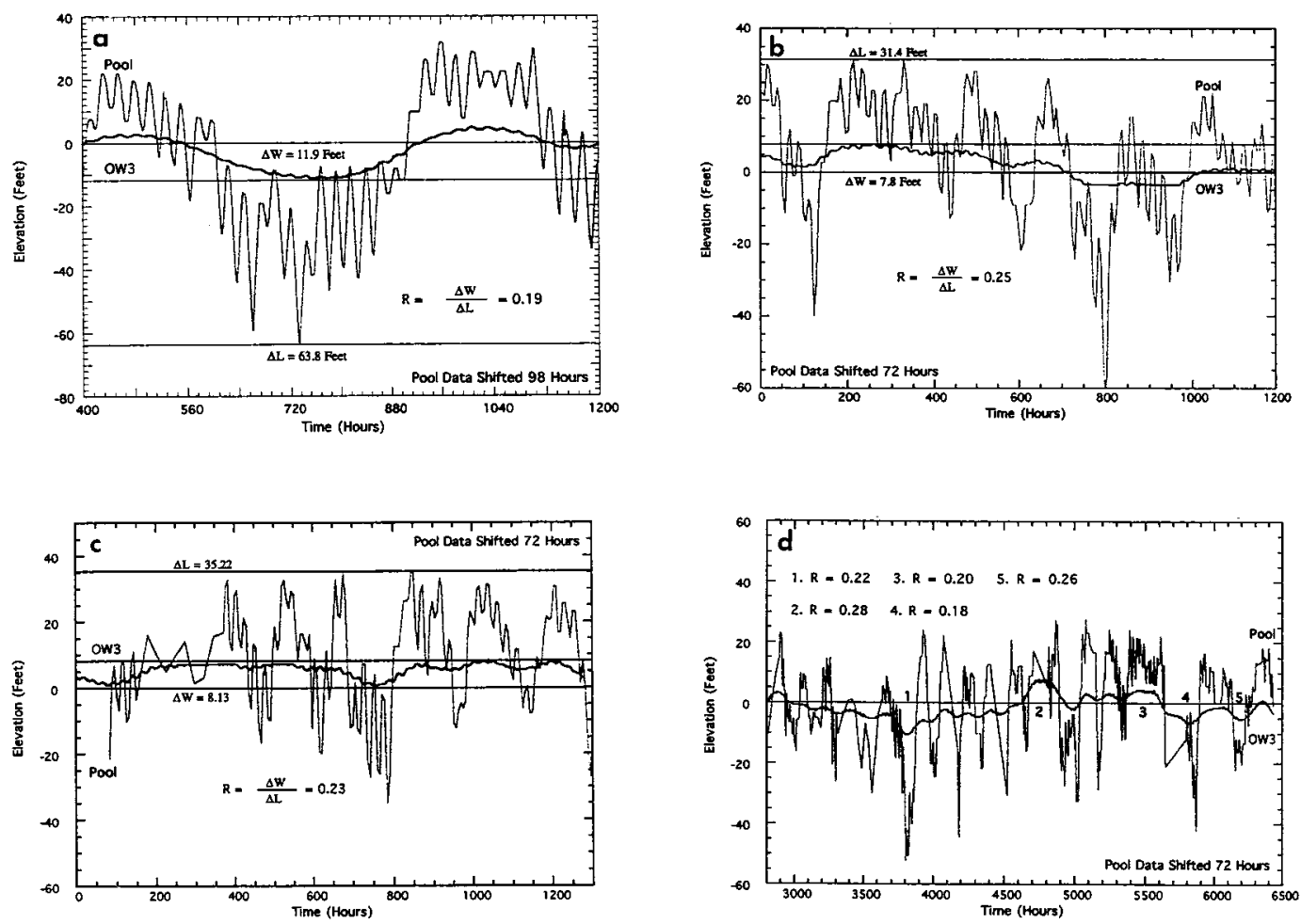

Figure 7. Comparison of deviations from the mean water levels in the lake $(\Delta L)$ and OW3 $(\Delta W)$ used to calculate $R$ for different time periods. (a) July 2 to August 6, 1992, (b) August 11 to September 30, 1994, (c) July 19 to September 10, 1995, and (d) November 13, 1995 to April 12, 1996.

The coefficient of permeability, $K$, in geotechnical literature is the same as hydraulic conductivity in geohydrological literature. The shear zone was encountered in four boreholes at depths ranging from $\sim 6.7$ to $17.4 \mathrm{~m}$ below the surface. The hydraulic conductivity, $K$, is related to permeability, $k$, by the relation

$$
K=k g \rho / \mu
$$

where $g$ is the acceleration due to gravity, $\mu$ is dynamic fluid viscosity, and $\rho$ is the density of water.

The hydraulic conductivity values in the four boreholes were $2.2 \times 10^{-8}, 5.6 \times 10^{-8}, 4.4 \times 10^{-7}$, and $2.1 \times 10^{-6} \mathrm{~m} \mathrm{~s}^{-1}$. Taking $\mu=10^{-3} \mathrm{~Pa}(\mathrm{~s})$ and $\rho=10^{3} \mathrm{~kg} \mathrm{~m}^{-3}, k$ was calculated from (4). The resulting permeability in the shear zone near the surface ranged between $2.2 \times 10^{-15}$ and $2.1 \times 10^{-13} \mathrm{~m}^{2}$. The lower end of the range $2.2 \times 10^{-15} \mathrm{~m}^{2}$ is probably more representative of the shear zone as a whole. This value agrees very well with that inferred from a comparison of the water levels (Table 2).

Table 2. In Situ Hydraulic Diffusivities and Permeabilities

\begin{tabular}{|c|c|c|c|c|}
\hline Period & $R$ & $\begin{array}{c}\Delta t, \\
\text { hours }\end{array}$ & $\begin{array}{c}C, \\
\mathrm{~m}^{2} \mathrm{~s}^{-1}\end{array}$ & $\begin{array}{c}\mathrm{k} \times 10^{-15} \\
\mathrm{~m}^{2}\end{array}$ \\
\hline June-Aug. 1992 & 0.19 & 98 & $0.052 \pm 0.001$ & $1.10 \pm 0.2$ \\
\hline $\begin{array}{l}\text { Aug. } 1994 \text { to } \\
\text { Jan. } 1995\end{array}$ & $\begin{array}{l}0.18-0.25 \\
\text { Average } \sim 0.22\end{array}$ & 72 & $0.080 \pm 0.002$ & $1.71 \pm 0.03$ \\
\hline July-Sept. 1995 & 0.23 & 72 & $0.083 \pm 0.002$ & $1.78 \pm 0.04$ \\
\hline $\begin{array}{l}\text { Nov. } 1995 \text { to } \\
\text { April } 1996\end{array}$ & $\begin{array}{l}0.18-0.25 \\
\text { Average } \sim 0.23\end{array}$ & 72 & $0.083 \pm 0.002$ & $1.78 \pm 0.04$ \\
\hline
\end{tabular}

\section{Spectral Analyses}

In comparing the time series representing the water levels in OW3 and Bad Creek (Figure 4), we see that there are some predominant long-period and short-period frequencies. In order to determine the predominant frequencies and their temporal behavior, we obtained the amplitude spectra for the water levels in OW3 and Bad Creek Reservoir for time sequence I, June 15 to August 29, 1992, and time sequence II, November 14, 1995, to November 2, 1996 [Cobb, 1997]. For both time sequences, the spectra for OW3 and Bad Creek Reservoir water levels showed similar predominant frequencies, as is illustrated by comparing the normalized amplitude spectra for sequence I (Figure 8). The dominant frequencies in Figure 8 correspond to periods of $28,17,12,7$, days and 1 day. For the longer sequence II, spectral peaks were obtained corresponding to periods of $68,31,17,12$, and 7 days and 1 day [Cobb, 1997]. For sequence I we note that for OW3 the amplitudes of the peaks corresponding to 7 days and 1 day are significantly smaller than those for peaks corresponding to 28 days, 17 days, and 12 days. The corresponding peaks for the lake levels do not show a similar difference. This observation suggested that the longer periods were more efficiently transmitted through the shear zone.

To seek the frequency response, the water level data were filtered using a narrow bandwidth Butterworth filter. Figure 9 shows the water levels for sequence II filtered through a Butterworth filter with a bandwidth corresponding to 26-36 days. This bandwidth encloses the predominant period of 31 days ( $T=31$ days) found in the amplitude spectra for sequence II. We note an excellent correlation between the two time series. 


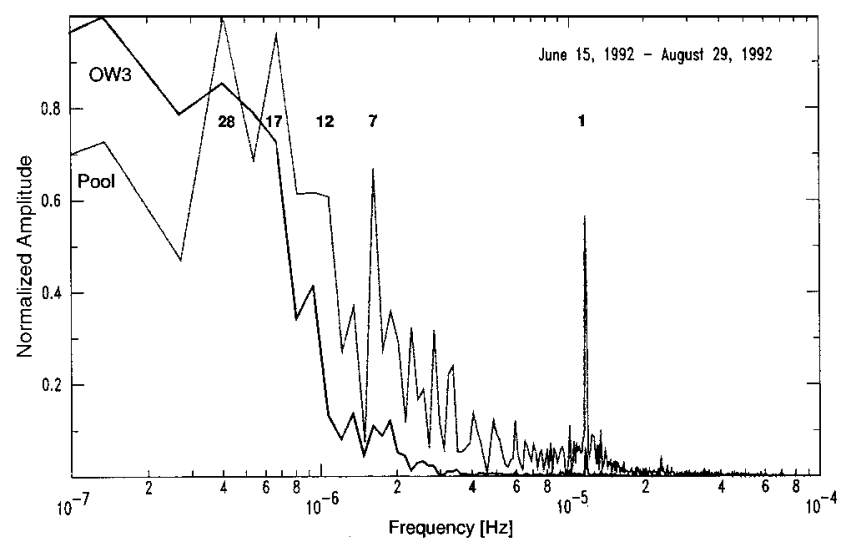

Figure 8. Normalized amplitude spectra of the water level time series for the lake and OW3 for the period June 15 to August 29, 1992. Note how both series have similar spectral peaks. The peaks correspond to periods (in days) of 28, 17, 12, 7 , and 1 , respectively.

correlation between the two time series yielded a lag, $\Delta t$, of 116 hours, and an amplitude ratio $R$ of 0.31 was obtained by comparing $\Delta W$ and $\Delta L$ for various peaks.

Using the method described for $T=31$ days, the amplitude ratio $R$ and time lag, $\Delta t$, were calculated for periods corresponding to spectral peaks for the water level time series for the two time sequences. The results are given in Table 3. We note that the longer periods are associated with larger ratios, $R$, and also larger time lags, $\Delta t$. These results are discussed later in section 5.3.

The amplitude ratio $R$ for both sequences showed an exponential relationship with the frequency of water level changes (Figure 10). The data fit the relationship

$$
R=0.50 \exp \left[-1.29\left(10^{6} f\right)\right] \pm 0.03
$$

where $f$ is the frequency in Hertz. In terms of period of water level changes $T$ (days) the data fit the relationship

$$
R=0.50 \exp (-14.93 / T) \pm 0.03
$$

The frequency dependent exponential decay of the pore pressure is the typical response to periodic changes in pore pressure at the surface. We use this observation to estimate the hydraulic diffusivity from phase data.

Following Todd [1959, pp. 163-165], if the lake level varies with a simple harmonic motion (which is equivalent to periodic pore pressure changes at the bottom of the reservoir), a sinusoidal pore pressure train propagates along the shear zone. With increasing distance away from the reservoir, amplitudes of the waves decrease and the time lag for a given maximum increases. For a one-directional flow in the shear zone, the applicable differential equation is given by (1) where $p$ is now harmonic and the applicable boundary conditions are $\tilde{p}=p_{0}$ Sin $\omega t$ at $r=0$ and $\tilde{p}=0$ at $r=\infty$. The angular velocity is $\omega$, for lake level changes with a period $T$,

$$
\omega=2 \pi / T
$$

The solution of (1) with these boundary conditions is

$$
\tilde{p}(r, \omega)=p_{0} e^{-r \sqrt{\omega / 2 C}} \operatorname{Sin}(\omega t-r \sqrt{\omega / 2 C})
$$

The ratio of the amplitudes of any period of the pore pressure change at a distance $r, \tilde{p}(r, \omega)$ to those at the lake $\tilde{p}(0, \omega)$ is given by

$$
\widetilde{R}=\tilde{p}(r, \omega) / \tilde{p}(0, \omega)=e^{-r \sqrt{\omega / 2 C}}
$$

The time lag of a given maximum or minimum after it occurs in the lake is given by

$$
\Delta t=r \sqrt{1 /(2 \omega C)}
$$

The phase velocity for a particular period is

$$
V_{w}=r / \Delta t=\sqrt{2 \omega C}
$$

The wavelength of a particular period is

$$
\lambda=2 \pi \sqrt{2 C / \omega}
$$

From (6) and (10) we get

$$
C=r^{2} T /\left[4 \pi(\Delta t)^{2}\right]
$$

The time lags, $\Delta t$, for various periods, $T$, are listed in Table 3 . Using (12), we obtained $C$. For example, the period $T=31$ days is associated with a time lag $\Delta t$ of 116 hours and $r=250$ $\mathrm{m}$; substituting in (12) yields $C=0.0764 \mathrm{~m}^{2} \mathrm{~s}^{-1}$.

The hydraulic diffusivity was calculated for the predominant frequencies in 1992 and 1996 (Table 3, Figure 10). The value of $C$ in 1992 varied between 0.089 and $0.046 \mathrm{~m}^{2} \mathrm{~s}^{-1}$ with an average value of $0.067 \mathrm{~m}^{2} \mathrm{~s}^{-1}$. The data suggest frequency dependence of $C$. However, in 1996 the calculated values of $C$ are frequency independent $\left(0.076 \pm 0.011 \mathrm{~m}^{2} \mathrm{~s}^{-1}\right)$. The data suggest a 13\% increase in $C$ between 1992 and 1996 for the average values. The $>50 \%$ increase calculated from (2) (Table 2) and frequency dependent values of $C$ for 1992 (Table 3) suggest that for the 2.5 month period in 1992 the shorter periods dominated.

\section{Determination of Skempton's Coefficient}

In section 3 we noted that for the short period changes in $\Delta L$ the load oscillates too fast compared to the time required for the pore pressures to diffuse to OW3. The response in the well approaches that of an undrained system; that is, the well seems to respond elastically, and pore pressure changes are induced by surficial loading or unloading with little or no delay (Table 3).

We use this observation to calculate the Skempton's coefficient, $B$, at the bottom of OW3. For a rapidly oscillating load

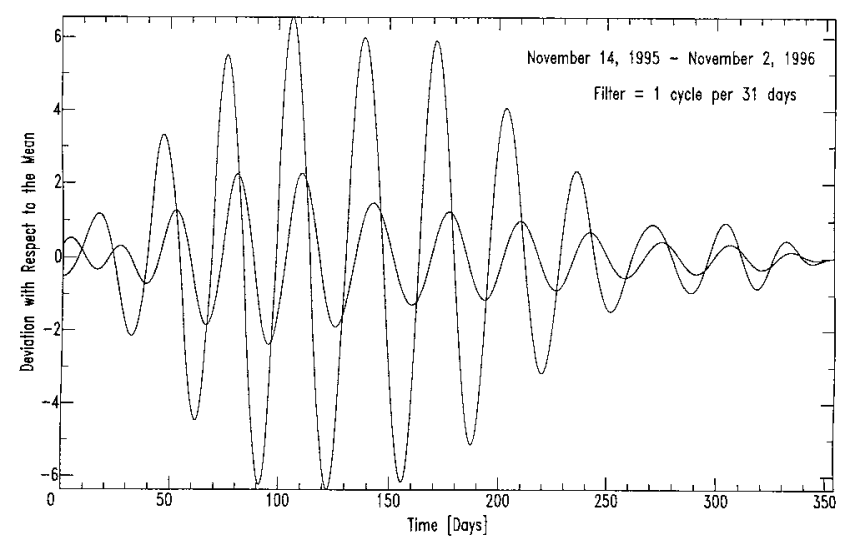

Figure 9. Smoothed water levels in the lake and OW3 after applying a Butterworth filter with a bandwidth corresponding to periods of 26-36 days. The larger amplitude curve is for the lake level. 
Table 3. Hydraulic Diffusivities From Phase Data

\begin{tabular}{|c|c|c|c|c|c|c|}
\hline \multirow[b]{2}{*}{$\begin{array}{l}\text { Period } T \\
\quad \text { days }\end{array}$} & \multicolumn{3}{|c|}{$\begin{array}{c}\text { Sequence I } \\
\text { June } 15 \text { to Aug. 29, } 1992\end{array}$} & \multicolumn{3}{|c|}{$\begin{array}{c}\text { Sequence II } \\
\text { Nov. 14, 1995, to Nov. 2, } 1996\end{array}$} \\
\hline & $R$ & $\begin{array}{l}\Delta t, \\
\text { hours }\end{array}$ & $\begin{array}{l}C^{*} \\
\mathrm{~m}^{2} \mathrm{~s}^{-1}\end{array}$ & $R$ & $\begin{array}{l}\Delta t, \\
\text { hours }\end{array}$ & $\begin{array}{c}C, \\
\mathrm{~m}^{2} \mathrm{~s}^{-1}\end{array}$ \\
\hline 31 & $\ldots$ & $\ldots$ & $\ldots$ & 0.31 & 116 & 0.076 \\
\hline 28 & 0.28 & 102 & 0.089 & $\ldots$ & $\cdots$ & . \\
\hline 17 & 0.23 & 90 & 0.070 & 0.23 & 86 & 0.076 \\
\hline 12 & 0.14 & 80 & 0.062 & 0.14 & 78 & 0.065 \\
\hline 7 & 0.06 & 71 & 0.046 & 0.07 & 52 & 0.086 \\
\hline 1 & 0.03 & $<3$ & & $\begin{array}{l}0.03 \\
(0.029)\end{array}$ & $\sim 0$ & $\cdots$ \\
\hline AVERAGE & & & 0.067 & & & 0.076 \\
\hline
\end{tabular}

${ }^{*} C$ calculated from phase velocity, equation (12).

at the surface in an undrained system, the changes in pore pressure, $d p$ at a point below are proportional to the changes in the mean stress, $d\left(\sigma_{k k} / 3\right)$,

$$
d p=-B d\left(\sigma_{k k} / 3\right)
$$

To calculate the mean stress change due to the reservoir fluctuations at the bottom of OW3, we treated the reservoir as a circular load.

For a circular load with radius $b$ subjected to uniform load $p$, the vertical $\left(\sigma_{z}\right)$, radial $\left(\sigma_{\rho}\right)$, and transverse $\left(\sigma_{t r}\right)$ stresses at a point at a radial distance $\rho$ from the center of the circular load and depth $z$ have been tabulated by Ahlvin and Ulery [1962] in terms of geometric functions. Each function is expressed in terms of both the depth and offset distance in radil $(z / b$ and $\rho / b)$, which identify the location of the point at which the stresses are calculated.

We take the radius of the Bad Creek Reservoir corresponding to the mean water level $(b=549 \mathrm{~m})$, the distance from the center of the reservoir to the top of the well $(\rho \sim 793 \mathrm{~m})$, and depth of the shear zone in the well $(z \sim 100 \mathrm{~m})$. The corresponding coordinates of the point for which we estimate the stresses expressed in terms of radii are $z / b \sim 0.2$, and $\rho / b \sim 1.5$.

From the tables [Ahlvin and Ulery, 1962, pp. 2-7], we get $\sigma_{z} / p=-0.008, \sigma_{\rho} / p=-0.038$, and $\sigma_{t r} / p=-0.085$ (compression taken to be negative). These values give a mean stress of $-0.044 p$

The ratio of the pore pressure changes in the well to those in

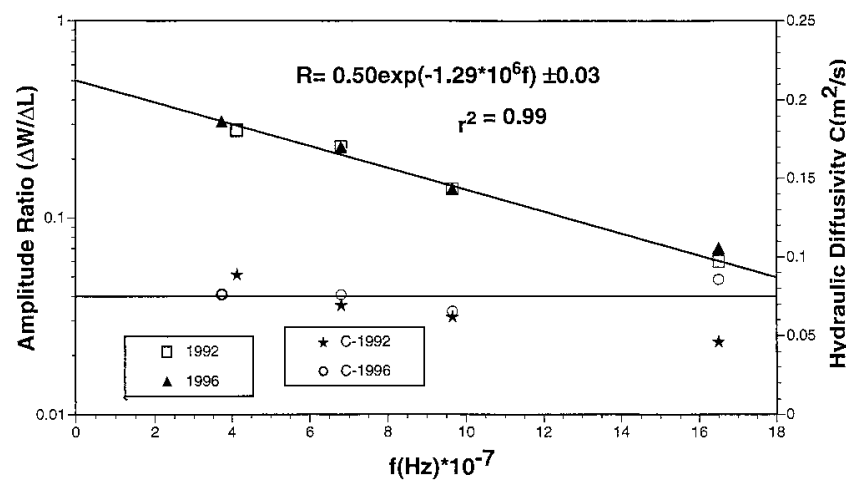

Figure 10. Empirically obtained relationship between $R$ and the frequency of water level changes and calculated values of hydraulic diffusivity plotted as a function of frequency. the lake from a filtered series corresponding to $T=1$ day (Table 3) is 0.029 ; that is, $d p / p=0.029$.

$$
B=-\frac{d p / p}{d\left(\sigma_{k k} / 3\right) / p}=0.66
$$

\section{Results and Discussion}

The results of a field experiment have led to in situ estimates of hydraulic diffusivity $\left(\sim 0.1 \mathrm{~m}^{2} \mathrm{~s}^{-1}\right)$ and permeability $(1-2 \times$ $10^{-15} \mathrm{~m}^{2}$ and temporal changes there in) of a narrow shear zone in crystalline rocks near Bad Creek Reservoir in northwestern South Carolina. These were obtained by comparing water level changes in a reservoir with correlative changes in an observation well connected to the reservoir by a saturated shear zone. Spectral analyses of the water level time series illustrated the frequency dependent behavior of the shear zone. The spectral data were further used to estimate an in situ value of $\sim 0.66$ for the Skempton's coefficient. These results and their implications are discussed next.

\subsection{Shear Zones Control Fluid Flow}

Shear zone $\mathrm{C}$ is one of six shear zones encountered during the construction of the Bad Creek project. It was encountered at six locations underground and was found to have a uniform thickness of $\sim 1 \mathrm{~m}$ over at least $1 \mathrm{~km}$ (Figure 6a) [Schaeffer, 1987]. Its appearance underground, about the powerhouse, was similar to that outcropping in the intake structure (Plate 1). Detailed mapping of the bedrock geology underground at the site of the powerhouse (Figure 6a) and at other locations revealed the presence of shear zones, continuous high-angle faults and hundreds of discontinuous joints. Of these, only the shear zone and, to a much lesser extent, the continuous highangle faults are the primary conduits of water at depth in the gneissic bedrock [Schaeffer, 1987]. In the underground works the only features transmitting water are the shear zones. Although the shear zones contain clay, the paths of fluid flow have been established around them. This observation attests to the inference that the flow of fluids (and fluid pressure) is limited to the continuous shear zones and is not affected by the ubiquitous presence of discontinuous joints. On the basis of the excellent coherence between short-period fluctuations in the lake and well water levels (Figure 5), we had inferred that the shear zone is saturated. This inference is borne out by the observation of the shear zones encountered in the underground works. 


\subsection{Homogeneous Behavior of Shear Zones}

The shear zones are parallel to the foliation which in turn is related to the second folding episode of the Toxaway gneiss. Thus, shear zone $\mathrm{C}$ is essentially a two-dimensional planar structure (Figure 6a and Plate 1), and its hydraulic properties were estimated by one-dimensional modeling of diffusion of harmonic fluid pressure changes along the shear zone. The wavelengths of the harmonic fluid pressure changes corresponding to the periods of lake level changes $(T>7 \mathrm{~d})$ are larger than the reservoir-well distance for which the permeability is estimated. At these temporal and spatial scales, the shear zone behaves homogeneously with respect to its hydraulic properties.

This contrasts with the heterogeneity often observed in permeability estimations of laboratory or core samples. Even in situ determinations of hydraulic conductivity of outcrops of shear zone $\mathrm{C}$ (described in section 2.3 ), the values varied by over 2 orders of magnitude, display heterogeneity at a outcrop scale. These observations suggest that care should be taken when projecting results of permeability measurements made on laboratory samples, or of in situ tests on outcrops, to larger depths and on longer timescales.

\subsection{Frequency Dependence of Pore Pressure Diffusion}

The one-dimensional model for the diffusion of sinusoidal pore pressure changes (in response to lake level fluctuations) fits the observations. The dependence of pore pressures at depths on the frequency of lake level fluctuations was observed and confirmed theoretical predictions of Roeloffs [1988], namely, $z=(2 C / \omega)^{1 / 2}$, where $z$ is the depth below which no pore pressure changes are felt due to lake level fluctuations at the surface with an angular frequency $\omega$. These results also offer an explanation for the observed phenomenon of Protracted Reservoir Induced Seismicity [Talwani, 1997], which is discussed in section 5.7.

\subsection{Temporal Changes in $C$ and $k$}

The temporal increase of $C$ and $k$ between 1992 and 1994 (Table 2) can possibly be explained by an observation from shear zone D. Drain holes were installed through shear zone D upstream of the powerhouse in the Penstock tunnel (Figure 6a) to relieve any build-up of pressure. Monitoring of these drains since early 1991 indicated that fines (even now in March 1998) are being removed from the shear zone. The continued presence of the fines in shear zone D in the Penstock tunnel, $\sim 1.5 \mathrm{~km}$ from the reservoir, 7 years after impoundment suggests that the flushing action of the reservoir is still ongoing. In contrast, by 1994, all the fines were flushed out of the $250 \mathrm{~m}$ portion of shear zone $\mathrm{C}$, between the reservoir and OW3, explaining the decrease in time lag from 98 hours in 1992 to 72 hours in 1994 and no further change. The flushing out of the fines led to a decrease in time lag and an increase in the calculated values of $C$ and $k$.

\subsection{Comparison of Hydraulic Diffusivity Values Obtained From Phase Data and Amplitude Ratios}

The hydraulic diffusivity was calculated from phase data (equation (12)) and from amplitude ratio of water levels (equation (2)). For the period 1994 and after, the average value of $C$ obtained from the phase data, $\sim 0.0764 \mathrm{~m}^{2} \mathrm{~s}^{-1}$ (Table 3), was lower than that from the amplitude ratios, $\sim 0.080-0.083 \mathrm{~m}^{2} \mathrm{~s}^{-1}$ (Table 2). The pore pressure at OW3 and hence $R$ in Table 2 contained both the undrained and drained response to loading. We subtracted 0.03 , corresponding to the undrained response from the amplitude ratios in Table 2, and recalculated $C$ using (2). The average of the corrected values of $C, \sim 0.0723 \mathrm{~m}^{2} \mathrm{~s}^{-1}$, was within about $5 \%$ the value obtained from phase data. This result suggests that the hydraulic diffusivity calculated from amplitude ratios (equation (2)) neglecting the undrained response to loading can lead to an overestimation of the true value of $C$ by about $5 \%$.

\subsection{Comparison of Observed Hydraulic Properties in Shear Zone C With Other Locations}

The frequency independent diffusivity value obtained for shear zone $C \sim 0.1 \mathrm{~m}^{2} \mathrm{~s}^{-1}$ lies in a range of values observed for fractured crystalline rocks $\left(0.1-10 \mathrm{~m}^{2} \mathrm{~s}^{-1}\right)$ [see, e.g., Roeloffs, 1997] and toward the low end of a range of values of $C$ estimated for various examples of induced seismicity. Those values of $C$ inferred from seismicity data cluster around $1 \mathrm{~m}^{2}$ $\mathrm{s}^{-1}$ and range between 0.1 and $10 \mathrm{~m}^{2} \mathrm{~s}^{-1}$ [Talwani and Acree, 1984; Rastogi et al., 1986]. Roeloffs [1988] noted that $C$ obtained from seismicity data by Talwani and Acree [1984] tended to be an upper bound value of $C$ as it did not consider the undrained response of the reservoir. Shapiro et al. [1997] obtained $C \sim 0.5-1 \mathrm{~m}^{2} \mathrm{~s}^{-1}$ from seismicity data associated with hydraulic-fracturing in the German Continental Drilling Borehole (KTB).

The observed values of hydraulic diffusivity at other sites of RIS in South Carolina $\left(\sim 5.0 \mathrm{~m}^{2} \mathrm{~s}^{-1}\right.$ at Lake Jocasse, $1.5 \mathrm{~m}^{2}$ $\mathrm{s}^{-1}$ at Clarks Hill Reservoir, and $\sim 2 \mathrm{~m}^{2} \mathrm{~s}^{-1}$ at Monticello Reservoir [Talwani, 1981]) are about an order of magnitude greater than those observed in the shear zone C. A possible explanation is the observation that the joint intensity at Bad Creek $\left(\sim 8 \mathrm{~m}^{2} / \mathrm{m}^{3}\right)$ is about $1 / 8$ that observed at Lake Keowee $\left(\sim 61.1 \mathrm{~m}^{2} / \mathrm{m}^{3}\right)$, the location of induced seismicity [Schaeffer, 1991]. The joint intensity, which is a measure of joint surface area per unit volume of rock $\left(\right.$ in $\left.\mathrm{m}^{2} / \mathrm{m}^{3}\right)$ is a loose measure of the permeability of the fractured rock. The calculated permeability, $1-2 \times 10^{-15} \mathrm{~m}^{2}$, for the shear zone lies in the range of values for crystalline rocks in the upper crust [see, e.g., Brace, 1984; Clauser, 1992] and at the upper end of those observed near the KTB hole at a depth of 7.5-9 km [Shapiro et al., 1997].

An in situ estimate was obtained for Skempton's coefficient for a location in fractured crystalline rocks at a depth of $\sim 100$ $\mathrm{m}$. The observed value of $B \sim 0.7$ lies in the range of values for quartzitic sandstone 0.56-0.72 [Houston and Kasim, 1982] and below those for Quincy granite (0.84-0.94) and Vermont marble (0.97-0.99). Houston and Kasim [1982] calculated those values of $B$ from elastic constants and porosity estimates. Values of $B$ calculated from laboratory measurements of elastic moduli vary with effective pressure. Roeloffs [1988] lists calculated values based on laboratory measurements for two granites. They range from 0.23 to 0.99 depending on the effective pressure. In a laboratory study of synthetic and natural sandstones, Berge et al. [1993] obtained B near 0.7-0.8 for differential pressures of about 8-21 $\mathrm{MPa}$. For differential pressures below $\sim 2 \mathrm{MPa}$, the measured values of $B$ were approximately unity.

\subsection{Implications for Reservoir Induced Seismicity}

The dependence of the pore pressures at depths on the frequency of lake level fluctuations was observed and confirmed theoretical prediction of Roeloffs [1988]. These results also offer an explanation for the observed phenomenon of 
protracted reservoir induced seismicity [Talwani, 1997]. Protracted RIS is that which is observed for long periods of time and does not die out a few years (or months) after impoundment. The best examples of protracted RIS are the ongoing (more than 30 years after impoundment) RIS at Koyna, India, and the RIS observed for over three decades near Lake Mead behind the Hoover Dam. The results of this study support the suggestion by Talwani [1997] that a major cause of the observed protracted RIS at Koyna, India, and Lake Mead is the large annual fluctuations in the lake level.

Acknowledgments. The earlier observations reported in this study were supported by the U.S. Geological Survey Award 1434-92-G-2199. We are also grateful to Duke Power Company for permission to carry out these studies on their premises and for sharing the lake level data. We also acknowledge with thanks the insightful and helpful comments by Evelyn Roeloffs and Frederick Paillet. We also thank Thomas Doe and Ian Lerche for their suggestions, Lynn Hubbard for word processing, and Rick Cannon for help with the illustrations.

\section{References}

Ahlvin, R. G., and H. H. Ulery, Tabulated values for determining the complete pattern of stresses, strains, and deflections beneath a uniform circular load on a homogeneous half space, Highw. Res. Board, Bull. 342, 1-13, 1962.

Bell, M. L., and A. Nur, Stress changes due to reservoir induced pore pressure and stresses and application to Lake Oroville, J. Geophys. Res., 83, 4469-4483, 1978.

Berge, P. A., H. F. Wang, and B. P. Bonner, Pore pressure buildup coefficient in synthetic and natural sandstones, Int. J. Rock. Mech. Min. Sci. Geomech. Abstr., 30, 1135-1141, 1993.

Bodvarsson, G., Confined fluids as strain meters, J. Geophys. Res., 75, 2711-2718, 1970

Brace, W. F., Some new measurements of linear compressibility of rocks, J. Geophys. Res., 70, 391-398, 1965.

Brace, W. F., Permeability of crystalline rocks: New in situ measurements, J. Geophys. Res., 89, 4327-4330, 1984.

Clauser, C., Permeability of crystalline rocks, Eos Trans. AGU, 73, 233, 237-238, 1992.

Cobb, J. S., In situ measurements of hydraulic diffusivity in a shear zone near Bad Creek Reservoir, South Carolina, Master's thesis, Univ. of S. C., Columbia, 1997.

Hatcher, R. D., Jr., Macroscopic polyphase folding illustrated by the Toxaway Dome, Eastern Blue Ridge, South Carolina-North Carolina, Geol. Soc. Am. Bull., 189, 143-162, 1977.

Healy, J. H., D. T. Rubey, D. T. Griggs, and C. B. Raleigh, The Denver earthquakes, Science, 161, 1301-1310, 1968.

Henderson, J. R., and B. Maillot, The influence of fluid flow in fault zones on patterns of seismicity: A numerical investigation, J. Geophys. Res., 102, 2915-2924, 1997.

Hill, D. P., A model for earthquake swarms, J. Geophys. Res., 82, $1347-1352,1977$

Houston, W. N., and A. G. Kasim, Physical properties of porous geologic materials, Spec. Pap. Geol. Soc. Am., 189, 143-162, 1982.

Howells, D. A., The time for a significant change of pore pressure, Eng. Geol., 8, 135-138, 1974.

Hsieh, P. A., and J. D. Bredehoeft, Some important aspects of a reservoir analysis of the Denver earthquakes: A case of induced seismicity, J. Geophys. Res., 86, 903-920, 1981.

Nur, A., and J. R. Booker, Aftershocks caused by pore fluid flow?, Science, 175, 885-887, 1972.

Rajendran, K., and P. Talwani, The role of elastic, undrained, and drained responses in triggering earthquakes at Monticello Reservoir, South Carolina, Bull. Seismol. Soc. Am., 82, 1867-1888, 1992.

Rastogi, B. K., B. R. Rao, and C. V. R. K. Rao, Microearthquake investigations near Sriramsagar Reservoir, Andhra Pradesh State, India, Phys. Earth Planet. Inter., 44, 149-159, 1986.

Rice, J. R., Fault stress states, pore pressure distributions and the weakness of the San Andreas Fault, in Fault Mechanics and Transport Properties of Rocks, edited by B. Evans and T.-F. Wong, pp. 475-503, Academic, New York, 1992.

Roeloffs, E. A., Fault stability changes induced beneath a reservoir with cyclic variation in water level, J. Geophys. Res., 93, 2107-2124, 1988.

Roeloffs, E. A., Poroelastic techniques in the study of earthquakerelated hydrologic phenomena, Adv. Geophys., 37, 135-195, 1997.

Schaeffer, M. F., Geology of the Keowee-Toxaway complex, northwestern South Carolina, in Association of Engineering Geologists, Field Trip Guidebook 1, 30th Annual Meeting, pp. 15-93, Assoc. Eng. Geol., Atlanta, Ga., 1987.

Schaeffer, M. F., A relationship between joint intensity and induced seismicity at Lake Keowee, northwestern South Carolina, Bull. Assoc. Eng. Geol., 28, 7-30, 1991.

Schaeffer, M. F., F. J. Hagye, R. E. Bryant, and L. E. McAuliffe, Detailed studies at the Bad Creek Project, Northwestern South Carolina, USA; Identification of geologic factors and their effects on construction and plant operation, paper presented at 28th International Geology Congress, 3, 3-38, 1989.

Shapiro, S. A., E. Huenges, and G. Borm, Estimating the crust permeability from fluid-injection-induced seismicity emission at the KTB site, Geophys. J. Int., 131, F15-F18, 1997. (Correction, Geophys. J. Int., 134, 913, 1998.)

Talwani, P., Earthquakes associated with the Clark Hill Reservoir, South Carolina; A case of induced seismicity, Eng. Geol., 10, 239 253, 1976.

Talwani, P., Hydraulic diffusivity and reservoir induced seismicity, final tech. rep., 48 pp., U.S. Geol. Surv., Reston, Va., 1981.

Talwani, P., Study of the correlation between water level fluctuation and reservoir induced seismicity; Phase I, National Earthquake Hazards Reduction Program, pp. 393-399, U.S. Geol. Surv., Reston, Va., 1990.

Talwani, P., On the nature of reservoir-induced seismicity, Pure Appl. Geophys., 150, 473-492, 1997.

Talwani, P., and S. Acree, Pore pressure diffusion and the mechanism of reservoir induced seismicity, Pure Appl. Geophys., 122, 947-965, 1984

Talwani, P., and J. Cobb, Induced seismicity studies at Bad Creek Reservoir, South Carolina, final tech. rep., 89 pp., U.S. Geol. Surv., Reston, Va., 1997.

Talwani, P., A. Ownby, K. Rajendran, M. Widdowson, and M. Schaeffer, A field study of reservoir induced seismicity at Bad Creek, South Carolina: The preimpoundment phase (abstract), Seismol. Res. Lett., 61, 162, 1990.

Todd, D. K., Ground Water Hydrology, 336 pp., John Wiley, New York, 1959.

U.S. Bureau of Reclamation, Designation E-18, Field Permeability Tests on Boreholes, in Earth Manual: A Water Resources Technical Publication, 2nd ed., pp. 573-578, U.S. Department of the Interior, Washington, D. C., 1974

Widdowson, M. A., M. E. Meadows, J. R. Dickerson, P. Talwani, M. Schaeffer, and W. H. Orne, Hydrologic impact of reservoir filling on a fractured crystalline rock aquifer, irrigation and drainage, paper presented at the National Conference, American Society of Civil Engineers, Honolulu, Hawaii, 1991.

J. S. Cobb and P. Talwani, Department of Geological Sciences, University of South Carolina, 701 Sumter Street-EWSC Room 517, Columbia, SC 29208. (talwani@prithvi.seis.sc.edu)

M. Schaeffer, Duke Engineering and Services, Inc., 400 South Tryon Street, WC23E, Charlotte, NC 28201.

(Received May 28, 1998; revised November 17, 1998; accepted February 9, 1999.) 
